\title{
Those Who Can Do: Wealth, Status, and Reproductive Success on Ifaluk
}

\author{
Paul W. Turke \\ Department of Anthropology, Northwestern University \\ L. L. Betzig \\ Museum of Zoology, University of Michigan
}

People everywhere require and therefore value resources. On Ifaluk, an atoll in the Western Carolines, salaried men, men of high status, and adults with living parents have more resources than other members of the population. The issue addressed here is whether differential success at acquiring resources leads to differential reproductive success. Analysis of Ifalukese age-specific fertility rates indicates the following:

1. Men who receive or once received salaries have greater reproductive success than any other category of men. Reasons include that they begin reproducing at especially young ages, have shorter than average birth intervals, and only rarely fail to reproduce altogether.

2. As a group, men with high status (chiefs, and their advisors and probable successors) have greater reproductive success than all never-salaried others. Reasons include shorter than average birth intervals and a somewhat lower than average chance of failing to reproduce altogether.

3. Individuals with longer-living parents achieve higher than average lifetime reproauctive success.

Key Words: Fertility; Wealth; Status; Rank

Thirty-Year-Old Ifaluk Male: So why are you here?

Anthropologist: To see how you spend your time. Same Ifaluk Male: That's easy, most of us spend our time trying to make babies.

\section{INTRODUCTION}

Modern Darwinian theory predicts that human behavior will be adaptive, that is, designed to promote maximum reproductive success (RS) through available descendent and nondescendent relatives. From this prediction, Irons (1979) has made the more specific prediction that cultural goals, to the extent that individuals actually strive for them, should promote RS, and that the most culturally successful individuals should therefore be the most reproductively successful. Support for this hypothesis has been accumulated from field research among Yomut Turkmen, Yanomamo Indians, rural Trinidadians, Lese, and modern Americans (Irons 1979; Chagnon 1979; 1980; 1982; Flinn 1983; Wrangham and Ross 1983; Essock-Vitale 1984), and from a worldwide cross-cultural sample (Betzig 1982; 1985). The analyses that follow add support.

\section{DESCRIPTION OF THE DATA, AND METHODS OF ANALYSIS}

The data to be analyzed were gathered during the summer and fall of 1983 on Ifaluk, an atoll of about one-half square mile in the Western Caroline Islands. Data collection techniques included observations and interviews. The latter provided a maximum of five and a minimum of two ascending generations of genealogical data

Received April 19, 1984; revised September 17, 1984.

Address reprint requests to: L.L. Betzig, Museum of $\mathrm{Zo}$ ology, Insect Division, University of Michigan, Ann Arbor, MI 48109. 
on every inhabitant, and it was from this source that demographic patterns were calculated. Information from a combination of observations and interviews led to the conclusion that residents valued resources and positions of wealth and status, and sought them whenever possible.

The population on Ifaluk at the time of our census numbered 446 individuals. Subsistence and to a slightly lesser extent local politics have changed little relative to conditions observed centuries ago (Burrows and Spiro 1957; Lutz 1980). Taro and breadfruit are primary carbohydrate and caloric sources, and are cultivated, harvested, and prepared mainly by women; fish provide an almost daily source of protein, and are usually caught by groups of men and then redistributed by chiefs and their advisors. Western food and technology are available only on a limited and irregular basis. The atoll's small size (both in area and population) and roughly 350mile distance from the deepwater port on Yap discourage economic relationships with the rest of the world. Western currency is available to the general population only through the sale of copra, which provides only about $\$ 10-\$ 30$ per month, per household. Money is used to purchase pots, knives, small amounts of cloth (for men's and boys' loin cloths), coffee, cigarettes, vodka, and even smaller amounts of canned meat, canned fish, baby food, and rice. Note, however, that these items come irregularly, unreliably, and very expensively, since they arrive only via a single "field-trip ship" serving the entire archipelago; consequently, reliance on them is minimal.

\section{Source of Wealth Differentials}

There is inequality within the Ifaluk economy. It has its basis both in the traditional status hierarchy and in the employment opportunities provided by the postwar, U.S.-administered U.N. trusteeship. Soon after its establishment, a small number of Ifaluk men began receiving salaries from the Trust Territory Administration for teaching at the newly established local elementary school, or for dispensing first aid and antibiotics as health care workers. This salaried work force has today grown to include 13 fulltime employees, 10 of them elementary school teachers, working about 40 hours per week at wages ranging from $\$ 1$ to $\$ 3$ per hour, and 4 part- time employees receiving equivalent hourly wages.

The wealth of these men is substantial by comparison to all other Ifalukese. This is evidenced by the diet of their families, which includes a greater proportion of Western food, and by their possession of kerosene lanterns and stoves, playpens and baby-walkers, transistor radios, and empty bottles, cans, and baby food jars. Moreover, it is these men and their families who are most likely to travel to the hospital on Yap during sickness and childbirth, both because they can more easily afford to do so (at about $\$ 12$ a head), and because they are more familiar with Western culture.

\section{Source of Status Differentials}

Local affairs on Ifaluk are governed by six male chiefs and by the male relative of one old female chief, who was so titled because of a lack of appropriate male heirs. Chiefly positions are heritable, the rule being that a current chief's successor will be his oldest sister's oldest son. Based on information from three informants, ten individuals are presently in the running as possible successors to the aforementioned seven, indicating that there is some uncertainty to succession and suggesting the possibility of limited competition for chiefly status. In addition to chiefs and their likely successors, two men, labeled chiefs' advisors, currently enjoy special status. Formerly, chiefs' advisors functioned primarily as bodyguards; today their roles appear to be limited to helping at redistributions and serving as chiefs' spokesmen at meetings. They are selected both according to genealogical proximity to the chief being advised (only the two highest male chiefs now have advisors) and perceived ability as an advisor (in the past, physical prowess was probably an important criterion).

Judging from the cross-cultural ethnographic record (e.g., Betzig 1985), and earlier Ifaluk ethnography (e.g., Burrows and Spiro 1957), it is likely that Ifaluk chiefs once enjoyed greater productive and reproductive privileges than they do presently. Current residents acknowledge that polygyny was once common among chiefs. Today, due to the longstanding presence of colonial powers and Christian influence, chiefs' means for sanctioning their authority is greatly reduced, as, according to informants, are their 
perquisites. These now include some tribute, the receipt of extra fish at redistributions, first and preferential serving at feasts, and a more leisurely life (Betzig 1984). Chiefs' advisors are similarly privileged, although to a somewhat lesser extent. Because perquisites to individuals with traditional status are decreasing, and the availability of Western currency and goods is increasing, the positive relationship between wealth and RS may be expected to be stronger than that between status and RS.

\section{RS Measures}

Since significant status and wealth differentials accrue to Ifaluk men to a far greater extent than to women, relationships between these variables and RS were sought only for men. RS was estimated from age-specific fertility measures that were first calculated for 5-year intervals for all living males at the age of 16 or older (no living Ifaluk male was reported to have reproduced before age 16). One hundred percent confidence of paternity was assumed; our impression was that this is probably not far off, at least for offspring born in wedlock. All but 10 of the births in the present analysis were legitimate, and pa- ternity assignments for the $\mathbf{1 0}$ illegitimates were provided and/or confirmed by the health aide who assisted in their births, and are considered reliable.

\section{Method of Analysis}

Differences in RS of men in different wealth and status categories do not, strictly speaking, require statistical verification since population parameters are presented. However, in order to justify generalizing from the data, parameters characterizing the entire Ifaluk population may be considered samples in either time or space, and accordingly it becomes necessary to evaluate the probability that apparent differences are real. For this purpose, differences in lifetime fertility, as well as differences in age-specific fertility, are evaluated with a maximum likelihood ratio calculated from $2 \times 4$ and $2 \times 3$ contingency tables by MIDAS, the University of Michigan statistical program.

\section{RESULTS}

Table 1 summarizes estimated RS (fertility) over 5 -year age intervals for every living male on Ifa-

Table 1. Male Age Specific Fertility

\begin{tabular}{|c|c|c|c|c|c|c|c|c|c|}
\hline \multirow{2}{*}{ Wealth/status category } & & \multicolumn{7}{|c|}{ Age interval } & \multirow[b]{2}{*}{ Total } \\
\hline & & $16-20$ & $21-25$ & $26-30$ & $31-35$ & $36-40$ & $41-45$ & $46-50$ & \\
\hline \multirow{2}{*}{$\begin{array}{l}\text { Full-time, part-time, and } \\
\text { retired salaried men, and } \\
\text { chiefs, advisors and } \\
\text { successors }\end{array}$} & $\overline{\bar{X}^{a}}:$ & 0.30 & 0.71 & 1.35 & 1.18 & 1.32 & 1.24 & 0.67 & \multirow[t]{2}{*}{6.77} \\
\hline & SD: & 0.59 & 0.88 & 1.24 & 0.86 & 1.26 & 1.44 & 0.83 & \\
\hline \multirow{2}{*}{$\begin{array}{l}\text { Full-time, part-time, and } \\
\text { retired salaried men }\end{array}$} & $\bar{X}:$ & 0.32 & 0.96 & 1.58 & 1.44 & 1.22 & 1.14 & 1.33 & \multirow[t]{2}{*}{7.99} \\
\hline & SD: & 0.61 & 0.98 & 1.27 & 0.79 & 0.79 & 0.99 & 0.90 & \\
\hline \multirow[t]{2}{*}{ Full-time salaried men } & $\bar{X}:$ & 0.46 & 1.58 & 1.63 & 1.43 & 2.00 & 2.00 & 2.00 & \multirow[t]{2}{*}{11.10} \\
\hline & SD: & 0.75 & 0.86 & 0.86 & 0.73 & 一 & - & - & \\
\hline \multirow{2}{*}{$\begin{array}{l}\text { Chiefs, successors, and } \\
\text { advisors }\end{array}$} & $\overline{\bar{X}}$ & 0.28 & 0.39 & 1.11 & 0.94 & 1.29 & 1.29 & 0.33 & \multirow[t]{2}{*}{5.63} \\
\hline & SD: & 0.56 & 0.59 & 1.15 & 0.85 & 1.45 & 1.62 & 0.62 & \\
\hline \multirow[t]{2}{*}{ Chiefs and successors } & $\bar{X}$ & 0.31 & 0.44 & 1.00 & 1.00 & 0.93 & 1.00 & 0.40 & \multirow[t]{2}{*}{5.08} \\
\hline & SD: & 0.58 & 0.61 & 1.12 & 0.87 & 1.06 & 1.35 & 0.66 & \\
\hline \multirow[t]{2}{*}{ Chiefs } & $\bar{X}:$ & 0.29 & 0.14 & 0.43 & 0.57 & 0.71 & 0.83 & 0.33 & \multirow[t]{2}{*}{3.30} \\
\hline & SD: & 0.45 & 0.35 & 0.73 & 0.73 & 0.88 & 1.21 & 0.75 & \\
\hline \multirow[t]{2}{*}{ Successors } & $\bar{X}:$ & 0.33 & 0.67 & 1.44 & 1.33 & 1.13 & 1.17 & 0.50 & \multirow[t]{2}{*}{6.57} \\
\hline & SD: & 0.67 & 0.67 & 1.17 & 0.82 & 1.17 & 1.46 & 0.50 & \\
\hline \multirow{2}{*}{$\begin{array}{l}\text { Others: neither full-time, part- } \\
\text { time, nor retired salaried, } \\
\text { chief, successor, or advisor }\end{array}$} & $\bar{X}:$ & 0.15 & 0.52 & 0.84 & 0.89 & 0.81 & 0.52 & 0.35 & \multirow[t]{2}{*}{4.05} \\
\hline & SD: & 0.39 & 0.69 & 0.94 & 1.05 & 1.25 & 1.10 & 0.68 & \\
\hline Total population: all men aged & $\bar{X}:$ & 0.20 & 0.60 & 1.07 & 1.03 & 1.06 & 0.88 & 0.51 & \multirow[t]{2}{*}{5.35} \\
\hline 16 or older & SD: & 0.48 & 0.78 & 1.11 & 0.97 & 1.28 & 1.33 & 0.77 & \\
\hline
\end{tabular}

$\bar{a} \bar{X}=b_{i} / n$, where $b_{i}$ is the total number of offspring born to living Ifaluk males during the $i$ th 5 -year interval, and $n$ is the total number of living men who are or ever have been in the ith interval. 
luk 16 and older according to wealth and status. The prediction that wealth and status relate positively to RS is borne out. (Note in regard to Table 1 that, for full-time salaried men, values in the last three age intervals are calculated from only one individual, and therefore 11.10 may be an imprecise estimate of lifetime fertility. Nevertheless, the pattern established in the four intervals spanning ages 16-35 strongly suggests that full-time salaried men will have higher lifetime fertility than any other category.)

The single exception is with regard to chiefs. As there are only seven male chiefs in the entire population, it is possible that sterility (or near sterility) caused by venereal disease in only one or two chiefs could have removed any positive relationship that might otherwise have existed. Findings in the cross-cultural literature indicating that chiefs commonly have had greater than average sexual access to women (e.g., Betzig, 1985; Kaplan and Hill, in preparation), coupled with evidence suggesting that venereal disease may have contributed to depopulation in nearby regions (Harvard University 1950), at least add plausibility to this argument as it pertains to Ifaluk. More solid evidence stems from the finding that one Ifaluk chief failed to reproduce at all, even though he was married to three successive women for a total of more than 40 years [cf. indications that failed reproductives in traditional cultures should be considered sterile (Poston 1983)]. Two others sired one child each while young, but none subsequently, although one was married three times. If those suspected of having had problems leading to sterility are removed from the sample of chiefs, those remaining have a mean lifetime fertility of 6.0 , which $i s$ above the population mean of 5.35. No matter what conclusion is drawn about current chiefs, the next generation of chiefs is clearly not troubled with sterility (antibiotics are now widely available) and they show signs of having greater RS than the population average.

Table 2 establishes that the positive relationships apparent in Table 1 between wealth, status, and RS are statistically significant. This suggests that they should exist elsewhere and at different times, given similar circumstances.

These results are further supported by the following equations, which regress fertility (number of children fathered to date $[F])$ on status $(C$ or $S$ ), controlling for year of birth $(Y)$. In the first equation, men of chiefly status (chiefs, advisors, and successors) are compared to men with neither chiefly nor salaried status: in the second, men of salaried status (full-time, parttime, and retired salaried men) are compared to men with neither status.

$$
\begin{gathered}
F=3.4954+\begin{array}{l}
2.0456 C \\
(0.0078)
\end{array}-\begin{array}{l}
0.0731 Y \\
(0.0002)
\end{array} \\
\left(R^{2}=0.2862\right) \\
F=4.3033+\begin{array}{l}
2.3407 S \\
(0.0001)
\end{array}-\begin{array}{l}
0.0959 Y \\
(0.0000) \\
\\
\left(R^{2}=0.3346\right)
\end{array}
\end{gathered}
$$

Both chiefly and salaried status are again found to be significant predictors of age-specific fertility $(p=0.0078$ and $p=0.0001$, respectively).

Napoleon Chagnon (1982) has found that, among the Venezuelan Yanomamo Indians, having a large number of kinsmen may be as important to one's RS as status or wealth. Chagnon emphasized the importance of altruism among collaterals and deemphasized the importance of grandparents, largely because grandparenting is relatively rare in his study population due to high adult mortality. Among the Ifalukese, however, adult mortality is low and most children under 16 have at least one living grandparent. Since the grandparental generation on Ifaluk is extremely productive, and production usually flows downward through the generations (Turke 1985), we looked for a relationship between RS of adults and number of living parents.

We found such a relationship in regressing fertility (number of children ego has produced to date $[F]$ ) on number of living parents ego has $(P)$ and year of ego's birth $(Y)$.

$$
\begin{aligned}
F=14.3333+\begin{array}{ll}
0.5233 P \\
(0.0304)
\end{array}- & 0.2335 Y \\
& (0.0000) \\
& \left(R^{2}=0.3914\right)
\end{aligned}
$$

This equation indicates that living parents have a positive effect on the RS of their adult offspring ( $p=0.0304)$.

\section{Mechanisms Underlying the Relationship Between Wealth, Status, and RS: Enhanced Mate Choice and Earlier Weaning}

Individuals vary in their reproductive potential. Relevant variables include age, health, differential ability to acquire and utilize resources, and other attributes indicative of genetic quality. In this light, mate choice is likely to affect RS considerably (e.g., Darwin 1871; Bateman 1948; Bateson 1983). 
Table 2. Contingency Tables Showing the Relationship Between Wealth, Status, and Reproductive Success

\begin{tabular}{|c|c|c|c|c|c|c|c|c|}
\hline & \multicolumn{4}{|c|}{$\begin{array}{l}\text { Number of children fathered by } \\
\text { men at age } 16-35\end{array}$} & \multicolumn{4}{|c|}{$\begin{array}{l}\text { Number of children fathered by } \\
\text { men at age } 16 \text { and over }\end{array}$} \\
\hline & 0 & $1-2$ & $3-4$ & $5+$ & 0 & $1-2$ & $3-4$ & $5+$ \\
\hline $\begin{array}{l}\text { Full-time, part-time, and retired } \\
\text { salaried men, and chiefs, } \\
\text { successors, and advisors }\end{array}$ & 3 & 14 & 8 & 11 & 3 & 10 & 5 & 18 \\
\hline \multirow[t]{2}{*}{ All others } & 38 & 17 & 16 & 7 & 37 & 17 & 10 & 14 \\
\hline & \multicolumn{4}{|c|}{$\begin{array}{l}\mathrm{MLR}^{a}=23.4346(\mathrm{df}=3) ; p= \\
0.0001\end{array}$} & \multicolumn{4}{|c|}{$\begin{array}{l}\mathrm{MLR}=22.3328(\mathrm{df}=3) ; p= \\
0.0001\end{array}$} \\
\hline $\begin{array}{l}\text { Full-time, part-time, and retired } \\
\text { salaried men }\end{array}$ & 1 & 8 & 3 & 8 & 1 & 8 & 3 & 8 \\
\hline \multirow[t]{4}{*}{ All others } & 40 & 22 & 20 & 8 & 39 & 19 & 11 & 21 \\
\hline & \multicolumn{4}{|c|}{$\begin{array}{l}\text { MLR }=20.1207(\mathrm{df}=3) ; p= \\
0.0002\end{array}$} & \multicolumn{4}{|c|}{$\begin{array}{l}\text { MLR }=16.5920(\mathrm{df}=3) ; p= \\
0.0009\end{array}$} \\
\hline & \multicolumn{4}{|c|}{$\begin{array}{l}\text { Number of children fathered by } \\
\text { men at age } 16-35\end{array}$} & \multicolumn{4}{|c|}{$\begin{array}{l}\text { Number of children fathered by men } \\
\text { at age } 16 \text { and over }\end{array}$} \\
\hline & 0 & & & $4+$ & 0 & & & $\overline{4+}$ \\
\hline \multirow[t]{2}{*}{$\begin{array}{l}\text { Full-time salared men } \\
\text { All others }\end{array}$} & $\begin{array}{r}0 \\
41\end{array}$ & & & $\begin{array}{r}7 \\
23\end{array}$ & $\begin{array}{r}0 \\
40\end{array}$ & & & $\begin{array}{r}7 \\
33\end{array}$ \\
\hline & \multicolumn{4}{|c|}{$\begin{array}{l}\text { MLR }=13.5597(\mathrm{df}=2) ; p= \\
0.0011\end{array}$} & \multicolumn{4}{|c|}{$\begin{array}{l}\text { MLR }=12.1242(\mathrm{df}=2) ; p= \\
0.0023\end{array}$} \\
\hline \multirow[t]{2}{*}{$\begin{array}{l}\text { Chiefs, advisors, and successors } \\
\text { All never-salaried others }\end{array}$} & $\begin{array}{r}2 \\
39\end{array}$ & & & $\begin{array}{r}3 \\
17\end{array}$ & $\begin{array}{r}2 \\
38\end{array}$ & & & $\begin{array}{r}9 \\
19\end{array}$ \\
\hline & \multicolumn{4}{|c|}{$\begin{array}{l}\text { MLR }=6.65337(\overline{d f}=2) ; p= \\
0.0359\end{array}$} & \multicolumn{4}{|c|}{$\begin{array}{l}\text { MLR }=10.1336(\mathrm{df}=2) ; p= \\
0.0063\end{array}$} \\
\hline \multirow[t]{2}{*}{$\begin{array}{l}\text { Chiefs and successors } \\
\text { All never-salaried others }\end{array}$} & $\begin{array}{r}2 \\
39\end{array}$ & & & $\begin{array}{r}3 \\
17\end{array}$ & $\begin{array}{r}2 \\
38\end{array}$ & & & $\begin{array}{r}7 \\
21\end{array}$ \\
\hline & \multicolumn{4}{|c|}{$\begin{array}{l}\text { MLR }=4.00146(\mathrm{df}=2) ; p= \\
0.1352\end{array}$} & \multicolumn{4}{|c|}{$\begin{array}{l}\mathrm{MLR}=11.4594(\mathrm{df}=2) ; p= \\
0.0032\end{array}$} \\
\hline
\end{tabular}

${ }^{a}$ MLR refers to maximum likelihood ratio.

It has already been established that, on Ifaluk, the wives and children of wealthy and high status males enjoy differential access to resources. It follows that wealthy and high status males should be in great demand as mates, and in turn should have great latitude of mate choice. Two predictions follow: (1) such males should be able to acquire mates and successfully reproduce at an earlier age than less well-endowed males; and (2) they should be able to choose females with especially high reproductive potential (important criteria of choice probably include the woman's health, age, whether she is or has been pregnant, indications of fidelity, and perhaps her wealth and status). Table 3 supports the first of these predictions for wealthy indi- viduals, but contradicts it for high status individuals (reasons for the late reproduction of high status men remain obscure). Table 4 , which demonstrates that the wives of wealthy men reproduce at especially young ages, supports prediction two. Prediction two is also given support by the finding that mates of wealthy and, to a lesser extent, high status males have shorter birth intervals than mates of others (see Table 5); and by the fact that the proportion of total reproductive failures is statistically significantly lower in salaried men $(p=0.0004)$, and almost so $(p=0.127)$ for high-status men (see Table 6).

Besides advantages in mate choice, wealthy and high-status individuals, because they have greater access to resources, are likely to have 
Table 3. Comparison of Father's Age at Birth of His First Offspring According to Wealth and Status ${ }^{a}$

\begin{tabular}{lccl}
\hline & $\bar{X}$ & SD & $n$ \\
\hline $\begin{array}{l}\text { Full-time salaried } \\
\quad \text { vs. }\end{array}$ & 21.76 & 4.25 & 13 \\
All others & 24.60 & 4.59 & $56>t=2.14, \mathrm{df}=19, p<0.025$ \\
$\begin{array}{l}\text { Full-time, part-time and retired salaried } \\
\quad \text { vs. }\end{array}$ & 22.89 & 4.05 & 19 \\
All others & 24.41 & 4.79 & $50>t=1.32$, df $=38, p<0.100$ \\
$\begin{array}{l}\text { Chiefs, advisors and successors } \\
\quad \text { vs. }\end{array}$ & 25.66 & 3.98 & 11 \\
All never salaried others & 23.95 & 4.96 & 40
\end{tabular}

a Degrees of freedom are calculated after Wonnacott and Wonnacott $(1977: 214) ; \bar{X}$ refers to mean age in years; SD refers to standard deviation.

Table 4. Comparison of Mother's Age at Birth of Her First Offspring According to Wealth and Status of Her Mate $^{a}$

\begin{tabular}{|c|c|c|c|}
\hline & $\overline{\bar{X}}$ & $\mathrm{SD}$ & $n$ \\
\hline $\begin{array}{l}\text { Mates of full-time salaried men } \\
\text { vs. }\end{array}$ & 19.54 & 3.38 & $\leqslant 0.01$ \\
\hline Mates of all others & 22.68 & 4.29 & 47 \\
\hline $\begin{array}{l}\text { Mates of full-time, part-time, and retired } \\
\text { salaried men } \\
\text { vs. }\end{array}$ & 20.63 & 3.65 & $3, p<0.05$ \\
\hline Mates of all others & 22.82 & 4.53 & $41-$ \\
\hline $\begin{array}{l}\text { Mates of chiefs, advisors and successors } \\
\text { vs. }\end{array}$ & 26.38 & 3.89 & \\
\hline Mates of all never-salaried others & 22.18 & 4.39 & 34 \\
\hline
\end{tabular}

${ }^{a}$ Degrees of freedom are calculated after Wonnacott and Wonnacott $(1977: 214) ; \bar{X}$ refers to mean age in years; SD refers to standard deviation.

Table 5. Average Birth Interval Lengths in Years According to Wealth and Status ${ }^{a}$

\begin{tabular}{llll}
\hline & $\bar{X}$ & SD & $n$ \\
\hline $\begin{array}{l}\text { Full-time salaried } \\
\text { men: mean age }=30, \mathrm{SD}=9\end{array}$ & 2.05 & 0.63 & 11 \\
$\quad$ vs. & 2.23 & 0.79 & 22 \\
All others: age $21-39$ & & & \\
$\begin{array}{l}\text { Full-time, part-time and retired salaried } \\
\text { men: mean age }=38, \mathrm{SD}=12\end{array}$ \\
$\quad$ vs.
\end{tabular}

${ }^{a}$ Age is accounted for, in that individuals within the groups being compared are nearly the same age. Dègrees of freedom are calculated after Wonnacott and Wonnacott (1977:214); $\bar{X}$ refers to mean age in years; SD refers to standard deviation. 
Table 6. Proportion of Reproductive Failures ${ }^{a}$

\begin{tabular}{|c|c|c|}
\hline & \multicolumn{2}{|c|}{ Number of Offspring Ever Produced } \\
\hline & 0 & 1 or More \\
\hline \multirow[t]{2}{*}{$\begin{array}{l}\text { Full-time salaried men: } \\
\text { Mean age }=30: \text { SD }=9 \\
\text { All others over age } 20\end{array}$} & $\begin{array}{r}0 \\
26 \\
\end{array}$ & $\begin{array}{l}13 \\
40 \\
\end{array}$ \\
\hline & $\overline{M L R}=11.5$ & $=0.0007$ \\
\hline $\begin{array}{l}\text { Full-time, part-time, and retired salar } \\
\text { Mean age }=38 ; \mathrm{SD}=12 \\
\text { All others over age } 26\end{array}$ & $\begin{array}{r}1 \\
20\end{array}$ & $\begin{array}{l}23 \\
38\end{array}$ \\
\hline All others over age 26 & $\mathrm{MLR}=12.6$ & $=0.0004$ \\
\hline \multirow[t]{2}{*}{$\begin{array}{l}\text { Chiefs, advisors, and successors: } \\
\text { Mean age }=55 ; \mathrm{SD}=9.1 \\
\text { All never-salaried others over age } 50\end{array}$} & $\begin{array}{l}2 \\
6\end{array}$ & $\begin{array}{r}11 \\
8\end{array}$ \\
\hline & Fisher's exac & \\
\hline
\end{tabular}

Age is accounted for in that individuals within the groups being compared are nearly the same age.

especially well-fed wives and children. Moreover, they have greater access to Western foods (e.g., cereals and prepared baby food; see above) and consequently may be able to wean children earlier. Better nutrition for mothers and earlier weaning of offspring are known to increase fertility by decreasing birth intervals (e.g., Howell 1979). Although we lack data on maternal nutritional status and age of weaning, the results in Table 5 do conform to this hypothesis.

\section{ALTERNATIVE EXPLANATIONS}

There are several alternative explanations for a correlation between wealth, status, and RS. One is that in some cultures, offspring appear to be economic assets (e.g., Cain 1977; Nag, White, and Peet 1978), and therefore families with many children would usually be especially wealthy. This is, however, not the case on Ifaluk. Thousands of observations made by random behavioral scans suggest that the productive activities of persons under age 20 are negligible (especially for males), both absolutely and in comparison to older individuals (Turke 1985). Furthermore, the wealth measure used in this analysis (salary) is independent of children's contributions to their father's wealth.

Another alternative is that adults with many children are more likely than others to have been awarded paying jobs. Enhanced group survival (or fitness) could be a goal of such behavior. However, this is unlikely to have been the case on Ifaluk, because virtually every salaried individual acquired his position before, or just after, embarking on his reproductive career. Contrary to a group adaptation hypothesis, wealthy and/or high-status men influence decisions about who is to receive a salary, and their actions appear to conform to Hamilton's (1963; 1964) rule: 4 out of 13 full-time positions are filled by sons or brothers of the wealthy and 2 others are filled by sons of high chiefs.

Finally, one might suggest that men with many children are consequently afforded high status. Again, data used in our analysis contradict this argument, in that status was defined as a function of being or becoming a chief, which in turn is decided by a rule that - at least todayis not subject to much manipulation (cf. Burrows and Spiro 1957).

\section{CONCLUSION}

For the capacity for culture to have evolved by natural selection, the behaviors it allowed must have been adaptive, at least at the time. This consequence is widely appreciated, but unfortunately the same cannot be said for another likely consequence: that the proximate mechanisms that kept cultural behavior adaptive initially might have kept it adaptive subsequently (Flinn and Alexander 1982; Turke, 1984). In 
this light, it is incautious to assume that humans have necessarily move along a cultural trajectory that is independent of their evolutionary history (e.g., Cloak 1975; Sahlins 1976; 1977; Pulliam and Dunford 1980; Montagu 1981).

This is not, however, to say that human behavior must be adaptive. There are potentially valid theories predicting the decoupling of culture from natural selection: natural selection may usually operate too slowly to have checked the development of major nonadaptive trends (even though it apparently did not do so for thousands or millions of years while the capacity for culture was evolving); and cultural evolution may have been significantly molded by selection of replicators other than genes, such as ideas or “memes" (Dawkins 1976; Durham 1976; 1982; Richerson and Boyd 1978; Cavalli-Sforza and Feldman 1981; and others). The crux here, however, is that neither of these modes of cultural evolution predicts that humans historically or currently strive to maximize genetic representation in future generations (Alexander 1979; Turke, 1984). Darwinian theory, on the other hand, makes such a prediction. The significance of this article is that it adds to the growing body of evidence that human behavior is, at least in preindustrial societies, largely adaptive. It has done so by demonstrating that on Ifaluk, two criteria of cultural success, wealth and status, are positively correlated with RS.

We thank participants in the annual Michigan-Northwestern-McMaster University Darwinian Discussion Group for many helpful comments. We would also like to thank Richard Alexander, William Dawson, and the University of Michigan Museum of Zoology for providing office space and computer access. Finally, we thank William Irons and two reviewers for thoughtful criticisms. Field research was supported by a grant from NSF to P.T. and from the Wenner-Gren Foundation to L.B.

\section{REFERENCES}

Alexander, R.D. Darwinism and Human Affairs. Seattle: University of Washington Press, 1979.

Bateman, A.J. Intrasexual selection in Drosophila. Heredity 2: 349-368 (1948).

Bateson, P.P.G., ed. Mate Choice. London: Cambridge University Press, 1983.

Betzig, L.L. Despotism and differential reproduction: A cross-cultural correlation of conflict asymmetry, hierarchy, and degree of polygyny. Ethology and Sociobiology 3: 209-221 (1982).
- Despotism and Differential Reproduction: $A$ Darwinian View of History. Hawthorne, NY: Aldine (1985).

- Redistribution: Equity or exploitation? Paper read at meetings of the American Anthropological Association (November 1984).

Burrows, E.G., Spiro, M.E. An Atoll Culture. Westport, CT: Greenwood Press, 1957.

Cain, M.E. The economic activities of children in a village in Bangladesh. Population and Development Review 3: 201-227 (1977).

Cavalli-Sforza, L., Feldman, M. Cultural Transmission and Evolution. Princeton: Princeton University Press, 1981.

Chagnon, N.A. Is reproductive success equal in egalitarian societies? In Evolutionary Biology and Human Social Behavior: An Anthropological Perspective, N.A. Chagnon, W. Irons (Eds.). North Scituate, MA: Duxbury Press, 1979, pp. 374-402.

- Kin selection theory, kinship, marriage, and fitness among the Yanomamo Indians. In Sociobiology; Beyond Nature/Nurture? G.W. Barlow, J. Silverberg (Eds.). Boulder: Westview Press, 1980, pp. 545-571.

- Sociodemographic attributes of nepotism in tribal populations. In Current Problems in Sociobiology, Kings' College Sociobiology Group (Eds.). Cambridge: Cambridge University Press, 1982, pp. 291318.

Cloak, F.T. Is a cultural ethology possible? Human Ecology 3: 161-182 (1975).

Darwin, C.R. The Descent of Man and Selection in Relation to Sex. London: John Murray, 1871.

Dawkins, R. The Selfish Gene: Oxford: Oxford University Press, 1976.

Durham, W. Interactions of genetic and cultural evolution: Models and examples. Human Ecology 10: 289-323 (1982).

Essock-Vitale, S.M. The reproductive success of wealthy Americans. Ethology and Sociobiology 5: 45-49 (1984).

Flinn, M.V. Resources, mating, and kinship: The behavioral ecology of a Trinidadian village. Ph.D. Dissertation, Northwestern University (1983).

- Alexander, R.D. Culture theory: The developing synthesis from biology. Human Ecology 10: 393-410 (1982).

Hamilton, W.D. The evolution of altruistic behavior. American Naturalist 97: 354-356 (1963).

- The genetical evolution of social behavior; I, II. Journal of Theoretical Biology 7: 1-52 (1964).

Harvard University. The Micronesians of Yap and Their Depopulation. Report of the Pcabody Museum Expedition to Yap, 1947-1948. Cambridge: Harvard University Press, 1950.

Howell, N. Demography of the Dobe Area !Kung. New York: Academic Press, 1979.

Irons, W. Cultural and biological success. In Evolutionary Biology and Human Social Behavior: An 
Anthropological Perspective, N.A. Chagnon, W. Irons (Eds.). North Scituate, MA: Duxbury Press, 1979, pp. 257-272.

Kaplan, H., Kill, K. Hunting ability and reproductive success among male Ache foragers; Preliminary results (in preparation).

Lutz, C. Emotion words and emotional development on Ifaluk atoll. Ph.D. Dissertation, Harvard University (1980).

Montagu, A., ed. Sociobiology Examined. London: Oxford University Press, 1980.

Nag, M., White, B., Peet, C. An anthropological approach to the study of the economic value of children in Java and Nepal. Current Anthropology 19: 293-306 (1978).

Poston, D.L. Estimating voluntary and involuntary childlessness in the developing countries. Journal of Biosocial Science 15 (1983).
Pulliam, H.R., Dunford, C. Programmed to Learn. New York: Columbia University Press, 1980.

Richerson, P.J., Boyd, R. A dual inheritance model of the human evolutionary process: I, basic postulates and a simple model. Journal of Social and Biological Structures 1: 127-154 (1978).

Sahlins, M.D. The Use and Abuse of Biology. Ann Arbor: University of Michigan Press, 1976.

Turke, P.W. Tests of Darwinian and economic models of reproductive behavior on Ifaluk and Yap. Ph.D. Dissertation, Northwestern University (1985).

- On what's not wrong with a Darwinian theory of culture. American Anthropologist 86: 663-668 (1984).

Wrangham, R.W., Ross, E. Correlates of reproductive success among the Lese. Paper read at a colloquium on evolutionary biology at Northwestern University (April 1983). 